\title{
Kajian Perlengkapan Senjata Rohani Berdasarkan Efesus 6:10-20 dan Implikasinya Bagi Orang Percaya Masa Kini
}

\author{
Nomin Bagau \\ Sekolah Tinggi Filsafat Theologia Jaffray Makassar
}

\begin{abstract}
ABSTRAK
Tujuan penulisan karya ilmiah ini adalah untuk menjelaskan tentang kajian perlengkapan senjata rohani dan implikasinya bagi orang percaya masa kini. Adapun metode penulisan yang digunakan adalah kuantitatif hermeneutik yaitu metode penelitian literatur (Library research), dengan menggunakan Alkitab, kamus, tafsiran, dan buku-buku serta berbagai tulisan-tulisan yang terdapat di media on-line, yang berhubungan dengan pembahasan dalam karya ilmiah penulis. Berdasarkan hasil uraian penulis dalam karya ilmiah tentang perlengkapan senjata rohani dan implikasinya bagi orang percaya masa kini, maka penulis dapat menarik kesimpulan. Pertama, harus mengenakan seluruh perlengkapan senjata Allah sebagai perlindungan. Kedua, setiap orang percaya harus mengenakan senjatasenjata yang Allah sediakan itu. Ketiga, dalam peperangan melawan musuh yang sesungguhnya harus andalkan kuasa Tuhan dalam kehidupannya.
\end{abstract}

Kata-Kata Kunci: Perlengkapan, senjata, musuh.

\section{BAB I}

PENDAHULUAN

\section{Latar Belakang Masalah}

Jemaat Efesus adalah orang-orang yang sudah percaya kepada Yesus Kristus. Penyebutan sebagai orang-orang percaya dalam Yesus Kristus merupakan orang-orang percaya di dalam Dia, tetap teguh dalam ketaatan kepada Dia serta kepada kebenaran dan jalan-jalan-Nya. ${ }^{1}$ Mereka bukanlah orang-orang kudus yang tidak setia, melainkan orangorang kudus yang percaya di dalam Kristus, sangat taat kepada-Nya, serta setia kepada pengakuan yang mereka buat kepada Tuhan mereka. Selain itu jemaat Efesus juga, Allah telah memilih sebelum dunia dijadikan, supaya kudus dan tak bercacat di hadapan-Nya (1:4). ${ }^{2}$ Ungkapan di dalam Dia Allah telah memilih kita bahwa Allah menghubungkan Kristus dan manusia dalam pikiran-Nya. Untuk mengangkat manusia yang pada saat itu belum menjadi anak-anak-Nya melalui karya Kristus yang menebus dan menjadikan sebagai anak-anak-Nya. Keputusan itu timbul dari kebaikan hati Allah, Ia memilih supaya

${ }^{1}$ Matthew Henry, Tafsiran Surat Galatia - Filemon (Surabaya: Momentum, 2015), 130.

${ }^{2}$ John R. W. Stott, Seri Pemahaman \& Penerapan Amanat Alkitab Masa Kini: Efesus (Jakarta: Yayasan Komunikasi Bina Kasih/OMF, 2003), 249. 
kita kudus dan tak bercacat di hadapan-Nya. ${ }^{3}$ Maksud dari ayat ini berarti menentukan dan mengasingkan terlebih dahulu, karena sudah diketahui terdahulunya. Pikiran ini disetujui dengan surat Roma 8: 29, sebab semua orang yang dipilih-Nya dari semula, mereka juga ditentukan dari semulanya untuk menjadi serupa dengan Anak-Nya. Betapa indahnya kedudukan orang saleh yang sudah dipilih dan diasingkan sebelum dunia dijadikan. Bukannya kamu yang memilih Aku melainkan Aku yang memilih kamu, serta menentukan kamu di dalam Yesus Kristus (Yoh. 15: 16). ${ }^{4}$

Secara khusus jemaat Efesus yang diselamatkan telah dipilih oleh Allah, dan telah menentukan mereka dari semula untuk menjadi anak-anak-Nya di dalam Kristus yang adalah Anak Allah sebelum dunia dijadikan (1:4-5). Keselamatan orang percaya tidak diperoleh karena usahanya sendiri, tetapi Allah sudah merencanakannya, suatu kebenaran yang sebaliknya dinyatakan melalui penentuan sejak semula (predestinasi) yang sesuai dengan kehandak dan kerelaan Allah (1:5) dan sekalian sesuai dengan maksud-Nya (1:11). ${ }^{5}$ Mengenai bagian ini, mereka telah mendengar firman kebenaran, yaitu Injil keselamatan, dan menjadikan itu sebagai milik mereka (1:13).

Walaupun jemaat Efesus sudah menjadi orang percaya dan Allah telah memilih mereka sebelum dunia dijadikan. Tetapi dalam kehidupan jemaat Efesus terjadi pemisahan dan perselisihan antara orang-orang non-Yahudi dan orang-orang Yahudi. Pemisahan ini secara jasmaniah bukan secara rohani bahwa orang non-Yahudi yang belum sunat secara lahiriah dinyatakan orang yang tidak percaya kepada Kristus; namun orang-orang yang telah sunat berarti mereka adalah orang-orang percaya disebut orang Yahudi. Orang-orang non-Yahudi mereka anggap orang yang tak bersunat. ${ }^{6}$ Tuntutan ini ditentang oleh Paulus. Ia katakan bahwa sunat Yahudi adalah "sunat daging", sunat yang dikerjakan oleh tangan manusia. Sunat ini tidak menyelamatkan. Ditinjau dari sudut ini "daging" orang Yahudi tidak berbeda dengan orang non-Yahudi (Kis. 11:2-3; Rom. 2: 25; Gal. 5:6). Jadi kalau orang-orang Yahudi menyebut orang-orang kafir orang-orang yang tak bersunat maka sebutan itu sebenarnya tidak mempunyai arti yang menentukan.

Ketika dalam jemaat Efesus terjadi pemisahan dan perselihan antara orang-orang non-Yahudi dan orang Yahudi. Orang-orang Yahudi beranggapan bahwa orang nonYahudi adalah musuh mereka, ditinjau dari ketidak sunatan mereka secara lahiria itu. Dengan mempertahankan argumen tersebut, dalam kehidupan jemaat Efesus saling membenci, memusuhi, menyimpan dendam, dan saling memisahkan antara orang nonYahudi dan orang Yahudi. Ketika terjadi permasalahan demikian dalam jemaat Efesus, banyak orang menganggap bahwa musuh mereka adalah orang-orang yang saling membenci dan memisahan mereka itu atau orang-orang yang berada di luar gereja yang tidak percaya kepada Yesus Kristus (orang-orang non-Yahudi). Jemaat Efesus sama sekali tidak mengetahui musuh mereka yang sesungguhnya yang dapat mengerjakan permasalahan dalam kehidupan mereka itu. Sehingga rasul Paulus menjelaskan kepada jemaat Efesus tentang musuh yang sesungguhnya dalam (6:12-13) untuk memberikan pemahaman tentang musuh yang sebenarnya yang sering mendatangkan permusuhan antara satu sama yang lain dalam kehidupan jemaat Efesus ini. Ini adalah musuh yang nyata yang selalu dihadapi oleh setiap orang-orang percaya di segala abad. Bukanlah musuh mereka itu manusia yang memiliki darah dan daging. Tetapi Iblis yang bekerja

22.

${ }^{3}$ R. A. Jaffray, Tafsiran Surat-Surat Paulus Kepada Orang Efesus (Makassar: Kalam Hidup, 1965),

${ }^{4}$ Peter T. O’Brien, Tafsiran Surat Efesus (Surabaya: Momentum, 2013), 63. 2016), 571.

${ }^{5}$ D. A. Carson \& Douglas J. Moo, An Introduction To The New Testament (Malang: Gandum Mas,

${ }^{6}$ J. L. Ch. Abineno, Tafsiran Surat Efesus (Jakarta: BPK Gunung Mulia, 1971), 54-55.

Ringkasan Skripsi Online Tahun Publikasi: 2020 
dibelakang layar untuk mengacaukan orang-orang yang benar-benar percaya kepada Yesus Kristus.

Pemisahan-pemisahan antara non-Yahudi dan orang Yahudi dipersatukan kembali oleh Yesus Kristus. Oleh kedatangan Kristus berakhirlah perbedaan itu dan terjadi kesatuan antara mereka di dalam Kristus. Kristus telah mempersatukan kedua pihak, dengan memperdamaikan dua kelompok manusia ini, yang tadinya cenderung saling menyakiti, saling membenci, dan saling mengecam. ${ }^{7}$ Yesus telah merubuhkan tembok pemisahan, yaitu perseturuan, tembok itu adalah hukum upacara yang menciptakan perselihan yang besar itu. Hukum itu disebut sebagai tembok pemisahan. Hal ini Matthew Henry mencatat dalam bukunya bahwa:

Semua upacara hukum telah dibatalkan oleh Kristus, karena telah di genapi di dalam Dia. Dengan menyingirkan penghalang ini, Kristus membentuk sebuah jemaat yang terdiri dari orang-orang percaya, baik Yahudi maupun bukan Yahudi. Dengan demikian Ia menciptakan menjadi satu manusia baru dalam diri-Nya. Ia membentuk kedua belah pihak menjadi satu kelompok yang baru, atau kumpulan umat Allah, mempersatukan mereka dengan diri-Nya sebagai kepala mereka, setelah mereka diperbaharuhi oleh Roh Kudus, dan sekarang telah sepakat di dalam cara penyembahan yang baru menurut Injil, dan dengan itu mengadakan damai sejahtera antara kedua belah pihak yang tadinya sangat berseteru. ${ }^{8}$

Dengan pengorbanan Kristus tembok-tembok pemisahan itu dipersatukan kembali di dalam Yesus Kristus. Walaupun sudah dipersatukan dan sudah menjadi orang-orang percaya di dalam Kristus. Tetapi sebagai manusia yang hidup dalam dunia yang fana ini, orang-orang percaya selalu diperhadapkan dengan peperangan rohani melawan seluruh alam semesta merupakan medan laga kejahatan dunia. ${ }^{9}$ Orang-orang Kristen tidak hanya berjuang melawan serangan-serangan dari manusia, tetapi juga berjuang melawan serangan dari kuasa-kuasa si jahat yang bergelut melawan Allah. Orang percaya memang tidak perlu memahami kata-kata Paulus secara harafiah; tetapi pengalaman sendiri cukup membuktikan bahwa di dunia ini ada kuasa jahat yang sangat giat bekerja. Sehingga Paulus mengajurkan kepada jemaat Efesus untuk mengenakan seluruh perlengkapan senjata Allah, sebagai alat perlawanan roh-roh jahat itu. Karena Paulus akan berpisah dengan mereka, ia memikirkan betapa beratnya perjuangan yang masih mereka akan hadapi. Maka Paulus mengajurkan untuk menggunakan seluruh perlengkapan senjata Allah bukan hanya sebagian perlengkapan senjata Allah.

Sehingga rasul Paulus mengajak kepada jemaat Efesus untuk mengenakan seluruh perlengkapan senjata Allah sebagai alat perlawanan roh-roh jahat. Karena peperangan yang dimaksudkan ini bukan melawan manusia atau peperangan secara jasmaniah, namun peperangan secara rohani melawan roh-roh jahat. Paulus melihat betapa beratnya peperangan yang akan dihadapi oleh jemaat Efesus, karena hidup ini sebagai perjuangan melawan Iblis dan pasukannya. Sehingga ia mengajurkan kepada jemaat Efesus untuk mengenakan seluruh perlengkapan senjata Allah. ${ }^{10}$ Sekalipun Allah telah menyediakan

${ }^{7}$ D. J. Wiseman \& J. I. Packer, Ensiklopedi Alkitab Masa Kini Jilid III (Jakarta: Yayasan Komunikasi Bina Kasih/OMF, 1982), 588.

${ }^{8}$ Matthew Henry, Tafsiran Surat Galatia - Filemon (Surabaya: Momentum, 2015), 160. 1983), 276.

${ }^{9}$ William Barclay, Pemahaman Alkitab Setiap Hari Galatia - Efesus (Jakarta: BPK Gunung Mulia, 2013), 995.

${ }^{10}$ Everett F. Harrison, Tafsiran Alkitab Wycliffe Volume 3 Matius - Wahyu (Malang: Gandum Mas,

Ringkasan Skripsi Online Tahun Publikasi: 2020 
seluruh perlengkapan senjata Allah untuk mengenakannya, kita harus sadar menghayati kuasa yang Tuhan Yesus Kristus telah disediakan untuknya. Supaya kamu bertahan melawan kejahatan itu. Sebab tanpa perlengkapan senjata dari Allah ini, orang Kristen tidak mampu bertahan.

Walaupun lewat pengorbanan Kristus telah diruntuhkan tembok pemisahan itu dan dipersatukan kembali di dalam diri-Nya. Tetapi masalah yang dihadapi dalam kehidupan jemaat Efesus, juga dihadapi oleh orang-orang percaya pada masa sekarang. Sepertinya dalam kehidupan orang-orang percaya terjadi pemecahan dengan beberapa denominasi gereja-gereja di provinsi papua antara lain. Bahwa ketika terjadi pemecahan antara denominasi Gereja Kemah Injil Indonesia (GKII) dengan Gereja Kemah Injil Papua (GKIP) sebagian besar orang mengatakan bahwa orang yang memecahkan gereja itu adalah musuh mereka. Kemudian dalam gereja terjadi pembunuhan antara satu yang sama lain dan membakar gereja-gereja yang dapat memusuhi mereka itu. Sebenarnya, hal itu terjadi bukan karena orang itu. Namun yang menyebabkan masalah itu adalah Iblis yang giat bekeja untuk mengacaukan orang-orang percaya. Iblis adalah musuh besar manusia yang medatangkan segala permusuhan, pemecahan, perselisihan, dan berbagai masalah dalam kehidupan orang-orang percaya di segala abad. Karena Iblis sangat tidak senang kalau setiap orang percaya bersatu di dalam Kristus Yesus. Sehingga Iblis bekerja keras untuk membangun kembali tembok-tembok pemisahan yang telah diruntukan oleh Yesus Kristus itu. Maka ia berjalan keliling sama seperti singa yang mengaum-aum dan mencari orang yang dapat ditelan (1 Ptr. 5: 8). Paulus melihat betapa beratnya peperangan melawan roh-roh jahat itu, maka Ia mengajarkan kepada setiap orang percaya untuk mengenakan seluruh perlengkapan senjata Allah, sebagai alat perlawanan roh-roh jahat yang sedang bekerja keras itu. Sebab, tanpa mengenakan perlengkapan senjata Allah itu, manusia tidak akan bertahan dalam masa peperangan itu. Hanya dengan mengenakan perlengkapan senjata Allah, manusia akan menang dalam peperangan melawan roh-roh jahat itu.

Sebagian orang Kristen saat ini tidak menyadari bahwa mereka berada dalam masa peperangan rohani melawan musuh yang sesungguhnya, yaitu pemerintah-pemerintah, penguasa-penguasa, penghulu-penghulu dan roh-roh jahat di udara. Ini adalah musuh orang percaya yang nyata, yang selalu diperhadapkan dalam kehidupan orang-orang percaya di segala abad. Sehingga Richard L. Pratt menyatakan bahwa:

Kebanyakan orang Kristen modern sulit menganggap kejahatan sebagai suatu kekuatan yang aktif. Kalau toh mereka percaya akan adanya dosa, maka dosa itu disamakan dengan tindakan-tindakan yang kita pilih sendiri. Kita bisa tertawa saat mendengar orang berkata: "Iblis membuat saya melakukan hal itu atau Iblis tidak membuat orang melakukan apapun! Kita (manusia) membantah. Sudah barang tentu kita sendiri yang memilih untuk berbuat dosa dan kita bertanggung jawab atas keputusan ini. Kita hidup di dalam dunia di mana kejahatan yang berada di luar diri kita berencana untuk menjatuhkan kita. ${ }^{11}$

Sesuai dengan pernyataan di atas banyak orang Kristen yang salah dalam mengambil suatu keputusan, sehingga membuat setiap orang kalah dalam peperangan rohani. Itu sebabnya, Paulus mengajurkan kepada jemaat Efesus untuk menggunakan seluruh perlengkapan senjata Allah. Hal ini bukan saja disampaikan kepada jemaat Efesus tetapi kepada semua orang percaya yang ada di setiap abad. Melihat Iblis giat bekerja keras 2012), 75 .

${ }^{11}$ Richard L. Pratt, Designed For Dignity; Dirancang Bagi Kemuliaan (Surabaya: Momentum,

Ringkasan Skripsi Online Tahun Publikasi: 2020 
untuk membangun kembali tembok-tembok yang telah diruntukan oleh Yesus Kristus lewat pengorbanan-Nya. Sepertinya yang di alami di papua antara Gereja Kemah Injil Indonesia (GKII) dan Gereja Kemah Injil Papua (GKIP) dalam memecahkan gereja dari Gereja Kemah Injil Indonesia menjadi Gereja Kemah Injil Papua. Sesudah memecahkan gereja antara kedua pihak ini, dalam gereja saling memusuhi dan saling memukul antara satu sama lain sampai beberapa orang mati tempat. Ketika melihat kejadian tersebut banyak orang menganggap musuh mereka adalah orang-orang yang melakukan kekerasan itu; pada kenyataannya bukan mereka itu. Sebenarnya semua itu terjadi oleh karena Iblis yang bekerja dibelakang layar untuk mengacaukan orang-orang percaya; karena Iblis sangat tidak senang kalau-kalau orang-orang percaya persatu di dalam Kristus. Itu sebabnya sebagai alat perlawanan musuhnya Allah mempersiapkan perlengkapan senjata Allah. Realitanya banyak orang Kristen saat ini yang hanya menggunakan sebagian perlengkapan senjata Allah. Sebenarnya Alkitab mengajurkan kepada orang-orang percaya adalah mengenakan seluruh perlengkapan senjata Allah, agar bertahan melawan Iblis. Maka itu penulis skripsi mengambil judul perlengkapan senjata rohani ini untuk memberikan pemahaman yang baik dan benar tentang mempergunakan seluruh perlengkapan senjata Allah dalam peperangan rohani.

Rasul Paulus memakai kata perlengkapan senjata rohani dalam surat Efesus dan kata perlengkapan senjata rohani memiliki makna yang sangat menarik untuk diteliti dan menggali kebenaran yang terkandung di balik kata perlengkapan senjata rohani. Penulis ingin mengetahui tentang konsep Paulus mengenai perlengkapan senjata rohani. Hal inilah yang melatar belakangi penulis untuk menulis karya ilmiah yang berjudul: KAJIAN PERLENGKAPAN SENJATA ROHANI BERDASARKAN EFESUS 6:10-20 DAN IMPLIKASINYA BAGI ORANG PERCAYA MASA KINI.

\section{Pokok Masalah}

Dengan melihat latar belakang masalah di atas, maka yang menjadi pokok permasalahan dalam penulisan skripsi ini adalah:

Pertama, apa sebenarnya makna di balik frasa perlengkapan senjata rohani berdasarkan Efesus 6:10-20?

Kedua, apa implikasi frase perlengkapan senjata rohani dalam kehidupan orangorang percaya masa kini?

\section{Tujuan Penelitian}

Sesuai dengan permasalahan yang diamati, maka tujuan dari penulisan skripsi ini adalah:

Pertama, untuk menganalisis dan menafsirkan makna di balik kata perlengkapan senjata rohani berdasarkan kitab Efesus 6:10-20.

Kedua, untuk membahas bagaimana implikasikan kata perlengkapan senjata rohani dalam kehidupan orang-orang percaya masa kini.

\section{Manfaat Penelitian}

Adapun manfaat dari penulis skripsi ini adalah sebagai berikut:

Pertama, untuk mencari tahu makna kata perlengkapan senjata rohani yang dipakai oleh rasul Paulus dalam kitabnya kepada jemaat Efesus.

Kedua, untuk mengembangkan ilmu dan menambah wawasan bagi penulis secara pribadi bagaimana mengeksegesis dan menafsirkan makna sebuah kata di dalam Alkitab.

Ketiga, sebagai bahan masukan bagi penulis untuk mengajarkan kepada jemaat dalam pelayanan ke depan. 
Keempat, untuk memenuhi salah satu persyaratan dalam menyelesaikan program strata satu (S1) di Sekolah Tinggi Filsafat Theologia Jaffray Makassar.

\section{Metode Penelitian}

Dalam penulisan skripsi ini, penulis menggunakan metode penelitian kuantitatif hermeneutik, ${ }^{12}$ yang mencakup eksegesis dan kajian Alkitab untuk memahami makna teks yang sesuai dengan konsep yang ada di dalam Efesus 6:10-20. Penulisan tidak mengadakan riset lapangan, tetapi hanya menggunakan metode penelitian literatur (research), terhadap berbagai sumber atau naskah-naskah yang memiliki kolerasi dengan judul, antara lain: Alkitab, tafsiran-tafsiran kitab Efesus, jurnal, dan buku-buku yang berhubungan dengan kata perlengkapan senjata rohani yang disusun secara diskriptif untuk mencapai sasaran dan tujuan penulisan. Penelitian-penelitian yang relevan yang berkaitan dengan konteks surat Efesus. ${ }^{13}$

\section{Batasan Penelitian}

Mengingat luasnya arti kata perlengkapan senjata rohani dalam Perjanjian Baru, penulis skripsi hanya akan membahas kata perlengkapan senjata rohani di dalam surat Efesus 6:10-20. Mengambil ayat-ayat firman Tuhan dari Perjanjian Baru dan Perjanjian Lama yang berkaitan dengan skripsi ini sebagai ayat referensi atau sebagai pendukung kata perlengkapan senjata rohani dalam Perjanjian Baru dan Perjanjian Lama.

\section{Sistematika Penulisan}

Sistematika penulisan karya ilmiah ini terdiri atas lima bab yang diklasifikasikan sebagai berikut:

Bab pertama, adalah bab awal yang berisi tentang pendahuluan: latar belakang masalah, pokok masalah, tujuan penelitian, manfaat penelitian, metode penelitian, batasan penelitian, dan sistematika penulisan.

Bab kedua, membahas tinjauan kepustakaan yaitu gambaran umum tentang surat Efesus, latar belakang surat Efesus, penulis surat Efesus, penerima surat Efesus, tema surat Efesus, tujuan penulisan surat Efesus, keadaan kota Efesus, keadaan jemaat Efesus.

Bab ketiga, membahas tentang penjelasan eksegesis dari kitab Efesus 6:10-20 meliputi perlengkapan senjata rohani, latar belakang, analisis struktur, analisis teks, analisis kata perbandingan terjemahan, menggunakan kata perlengkapan senjata rohani dalam surat Efesus dan kitab-kitab lain.

${ }^{12}$ Hengki Wijaya, Metodologi Penelitian Pendidikan Teologi (Makassar: Sekolah Tinggi Theologia Jaffray Makassar, 2016); Hengki Wijaya, Analisis Data Kualitatif Ilmu Pendidikan Teologi (Makassar: Sekolah Tinggi Theologia Jaffray Makassar, 2018).

${ }^{13}$ Darius Darius and Robi Panggarra, "Konsep Manusia Baru Berdasarkan Perspektif Paulus Dalam Efesus 4:17-32 Dan Implementasinya Dalam Kehidupan Orang Percaya," Jurnal Jaffray 11, no. 2 (October 2, 2013): 29-58, https://doi.org/10.25278/jj71.v11i2.80; Rose Melly Merang and Robi Panggarra, "Makna Kata Kharis Berdasarkan Surat Efesus 2:8 dan Implementasinya dalam Kehidupan Orang Percaya Masa Kini," Jurnal Jaffray 10, no. 2 (October 1, 2012): 70-103, https://doi.org/10.25278/jj71.v10i2.54; Selvester

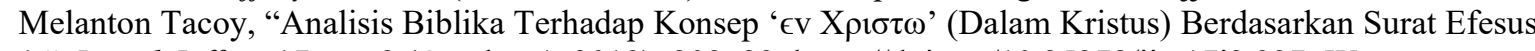
1,” Jurnal Jaffray 17, no. 2 (October 1, 2019): 203-22, https://doi.org/10.25278/jj.v17i2.337; Wangyu Wangyu and Robi Panggarra, "Konsep Eirene Berdasarkan Efesus 2:11-22 dan Implementasinya dalam Kekristenan Masa Kini," Jurnal Jaffray 8, no. 2 (October 1, 2010): 86-105,

https://doi.org/10.25278/jj71.v8i2.49; Hengki Wijaya, "Pengenaan Manusia Baru Di Dalam Kristus: Natur, Proses, Dan Fakta Serta Implikasi Teologis Dan Praktisnya," Jurnal Jaffray 14, no. 1 (March 22, 2016): 10930, https://doi.org/10.25278/jj71.v14i1.194.

Ringkasan Skripsi Online Tahun Publikasi: 2020 
Bab keempat, merupakan implikasi bagi orang percaya masa kini.

Bab kelima, penutup yaitu, kesimpulan dan saran.

\section{BAB V \\ KESIMPULAN DAN SARAN}

\section{Kesimpulan}

Setelah membahas beberapa bab sebelumnya, maka pada bab ini penulis akan memberikan beberapa kesimpulan tentang kajian perlengkapan senjata rohani berdasarkan Efesus 6:10-20 dan implikasinya bagi orang percaya masa kini. Berikut adalah beberapa kesimpulan berikut, yaitu:

Pertama, perlengkapan senjata rohani merupakan bagian yang sangat penting bagi kehidupan orang percaya. Kehidupan orang percaya juga rentan terhadap berbagai peperangan yang terjadi atas kehidupan orang percaya dan musuh-musuh Allah. Di dalam setiap keadaan yang dialami oleh orang percaya, tanpa disadari sebetulnya orang percaya sedang berperang melawan kuasa-kuasa kegelapan. Paulus menyadari hal tersebut, sehingga kemudian Paulus pun menuliskan pengajaran tentang pentingnya perlengkapan senjata rohani bagi orang percaya. Pengajaran ini adalah untuk mengingatkan kembali akan pentingnya kesadaran bahwa hidup orang percaya adalah sebuah peperangan baik dalam roh maupun di dalam daging. Karena itu, menggunakan setiap perlengkapan senjata rohani dapat menolong orang percaya untuk kuat menghadapi peperangan iman yang terjadi.

Kedua, hidup di dalam kejujuran. Kejujuran tidak hanya menjadi sikap hidup orang percaya. Tipu muslihat yang menjadi cara utama iblis hanya bisa dilawan dengan kejujuran yang dinyatakan di dalam berbagai hal. Paulus menuliskan bahwa setiap orang percaya juga perlu memakai baju zirah yang berkaitan dengan kejujuran. Tipu muslihat iblis yang dilakukan dalam berbagai cara, hanya bisa diperangi dengan cara dan sikap hidup yang bena, yakni dengan hidup dalam kejujuran. Sebab itu, setiap orang percaya pun perlu menyadari hal ini dan dengan tekun dapat hidup di dalam kejujuran yang dikehendaki Allah.

Ketiga, perlengkapan rohani yang benar didasarkan pada mengandalkan Yesus. Paulus menegaskan tentang pentingnya mengandalkan Yesus sebagai dasar utama hidup orang percaya. Peperangan yang terjadi di antara pengikut Yesus dan kuasa kegelapan hanya bisa dikalahkan dengan iman kokoh pada kemenangan Kristus. Yesuslah yang menjadi pemilik kemenangan hidup orang percaya. Karena itu, Paulus menjelaskan semua hal ini di dalam teks Efesus 6 tentang perlengkapan senjata rohani. Orang percaya hanya bisa berkemenangan dengan mengandalkan Yesus, dan bukan hal-hal lainnya.

Keempat, peperangan rohani juga berkaitan dengan pemberitaan Injil. Paulus mengatakan bahwa Injil adalah kekuatan Allah yang menyelamatkan. Orang-orang yang terikat dengan kuasa kegelapan sangat memerlukan adanya berita Injil. Jelas bahwa pemberitaan Injil demi menyelamatkan juga menjadi suatu peperangan. Karena itu, Paulus telah meminta jemaat untuk saling mendoakan terutama mendoakan orang-orang yang memberitakan Injil. Jadi, pada dasarnya pemberitaan Injil pun adalah peperangan rohani, di mana setiap orang percaya juga memerlukan perlengkapan rohani untuk berperang dan bertahan melawan kuasa kegelapan.

Kelima, memiliki identitas yang baru di dalam Kristus menjadi tantangan yang baru bagi orang percaya. Paulus menuliskan tentang pentingnya perlengkapan rohani, sebab kehidupan identitas orang percaya selalu diperhadapkan dengan berbagai pekerjaan dari

Ringkasan Skripsi Online Tahun Publikasi: 2020 
kuasa kegelapan. Itulah yang menjadi dasar Paulus menuliskan pengajarannya tentang perlengkapan senjata rohani yang harus dimiliki oleh orang percaya. Oleh sebab itu, maka pentingnya bagi orang percaya untuk menyadari bahwa hidup sebagai anak-anak Allah juga berarti hidup di dalam peperangan melawan kuasa kegelapan.

Keenam, menjaga pikiran sejalan dengan menggunakan ketopong keselamatan. Paulus dengan sengaja menuliskan tentang pentingnya menjaga pikiran terhadap hal-hal yang jahat yang dipakai oleh kuasa kegelapan untuk menjatuhkan dan mencemarkan kehidupan orang percaya. Pikiran adalah tempat di mana terjadi peperangan rohani. Allah tentu menghendaki agar pikiran setiap percaya dapat diarahkan pada Yesus dan kebenaran firman-Nya sehingga orang percaya dapat bertahan melawan kuasa kegelapan.

Ketujuh, menggunakan pedang Roh ini. Senjata rohani yang dituliskan oleh Paulus tidak saja dipergunakan untuk bertahan menghadap berbagai pekerjaan kuasa kegelapan, tetapi dipakai juga untuk melawan kuasa kegelapan. Pedang roh yang dimaksudkan oleh Paulus jelas merujuk pada pentingnya firman Tuhan yang sangat penting bagi orang percaya sehingga orang percaya dapat bekerja sesuai kebenaran Allah untuk melawan kuasa kegelapan. Jadi, menggunakan pedang roh berarti menggunakan firman Tuhan sebagai senjata untuk melawan kuasa kegelapan.

Kedelapan, doa adalah senjata rohani. Paulus menuliskan bahwa jemaat di Efesus perlu saling mendoakan. Tentu hal ini sangat penting sebagai bagian dari perlengkapan senjata rohani. Saling mendoakan adalah sikap yang penting di antara orang percaya. Tanpa doa, maka sebetulnya akan sulit bagi orang percaya untuk bertahan melawan berbagai pekerjaan kuasa kegelapan. Karena itu, Paulus kembali mengingatkan hal ini di dalam pengajarannya tentang perlengkapan senjata rohani.

\section{Saran-saran}

Selain memberikan beberapa kesimpulan, penulis juga akan memberikan beberapa saran yang penting bagi kehidupan orang percaya di masa kini. Berikut adalah beberapa saran tersebut, yaitu:

Pertama, kehidupan orang percaya tidak lepas dari adanya perlawanan dari kuasa kegelapan. Kesadaran bahwa kehidupan Kristen yang tak pernah lepas dari pekerjaan si jahat, maka penting untuk terus menjaga kehidupan sesuai dengan kebenaran dan pengajaran yang dikehendaki Allah, bukan hanya dipahami tetapi juga perlu dilakukan dengan kesadaran yang benar.

Kedua, tipu muslihat adalah salah satu pekerjaan dari kuasa kegelapan yang sering dipakai untuk menjauhkan bahkan menjatuhkan orang percaya. Sikap yang dapat dilakukan oleh orang percaya ialah hidup di dalam kejujuran. Karena itu, hendaknya sebagai umat Allah, orang percaya pun harus menunjukkan identitas diri sebagai orangorang selalu hidup di dalam kejujuran, bukan hidup di bawah tipu muslihat iblis.

Ketiga, memelihara pikiran sesuai kehendak Allah dan melakukan firman-Nya merupakan bagian dari senjata rohani yang dapat membuat orang percaya kuat di dalam menghadapi peperangan rohani. Maka, hendaknya hal ini dapat menjadi ciri utama dari kehidupan orang percaya, sehingga dengan kekuatan Allah, orang percaya dapat bertahan melawan kuasa kegelapan.

Keempat, identitas yang baru di dalam Kristus juga menjadi suatu tantangan yang baru sebagai orknum-oknum yang akan terlibat di dalam peperangan rohani. Sebab itu, setiap orang percaya perlu menyadari bahwa keadaan yang baru di dalam Kristus, bukanlah kehidupan yang biasa saja, melainkan juga menghadirkan berbagai masalah terutama dengan melawan kuasa kegelapan.

Kelima, hidup dengan saling menguatkan dan mendoakan adalah ciri hidup utama dari setiap orang percaya. Paulus pun telah menegaskan hal tersebut di dalam suratnya

Ringkasan Skripsi Online Tahun Publikasi: 2020 
kepada jemaat Efesus. Hal ini pun berlaku bagi kehidupan orang percaya zaman kini. Karena itu, maka penting bagi orang percaya untuk saling mendoakan sebagai bagian dari kehidupan bersama di dalam Kristus, yang saling mendukung dan menguatkan terutama di dalam bertahan kuasa kegelapan.

\section{KEPUSTAKAAN}

Abineno, J. L. Ch. Tafsiran Surat Efesus. Jakarta: BPK Badan Penerbitan Kristen, 1971. Barclay, William. Pemahaman Alkitab Setiap Hari Galatia - Efesus. Jakarta: BPK Gunug Mulia, 1983.

Brien, Peter O Tafsiran Surat Efesus. Surabaya: Momentum Christian Literature, 2013.

Carson, D. A. \& Douglas J. Moo. An Introduction To The New Testament. Malang: Gandum Mas, 2016.

Darius, Darius, and Robi Panggarra. "Konsep Manusia Baru Berdasarkan Perspektif Paulus Dalam Efesus 4:17-32 Dan Implementasinya Dalam Kehidupan Orang Percaya." Jurnal Jaffray 11, no. 2 (October 2, 2013): 29-58. https://doi.org/10.25278/jj71.v11i2.80.

Harrison, Everett F. Tafsiran Alkitab Wycliffe Volume 3 Matius - Wahyu. Malang: Gandum Mas, 2013.

Henry, Matthew Tafsiran Surat Galatia Sampai Filemon. Surabaya: Momentum Christian Literature, 2015.

Jaffray, R. A. Tafsiran Surat-Surat Paulus Kepada Orang Efesus. Makassar: Kalam Hidup, 1965.

Merang, Rose Melly, and Robi Panggarra. "Makna Kata Kharis Berdasarkan Surat Efesus 2:8 dan Implementasinya dalam Kehidupan Orang Percaya Masa Kini." Jurnal Jaffray 10, no. 2 (October 1, 2012): 70-103. https://doi.org/10.25278/jj71.v10i2.54.

Pratt, Richard L Designed For Dignity; Dirancang Bagi Kemuliaan. Surabaya: Momentum Christian Literature, 2012.

Stott, John R.W.Seri Pemahaman \& Menerapan Amanat Alkitab Masa Kini Efesus. Jakarta: Yayasan Komunikasi Bima Kasih/OMF, 2008.

Tacoy, Selvester Melanton. “Analisis Biblika Terhadap Konsep ‘ $\epsilon \mathrm{V}$ X $\rho \_\tau \omega$ ' (Dalam Kristus) Berdasarkan Surat Efesus 1.” Jurnal Jaffray 17, no. 2 (October 1, 2019): 203-22. https://doi.org/10.25278/jj.v17i2.337.

Wangyu, Wangyu, and Robi Panggarra. "Konsep Eirene Berdasarkan Efesus 2:11-22 dan Implementasinya dalam Kekristenan Masa Kini." Jurnal Jaffray 8, no. 2 (October 1, 2010): 86-105. https://doi.org/10.25278/jj71.v8i2.49.

Wijaya, Hengki. Analisis Data Kualitatif Ilmu Pendidikan Teologi. Makassar: Sekolah Tinggi Theologia Jaffray Makassar, 2018.

Wijaya, Hengki. Metodologi Penelitian Pendidikan Teologi. Makassar: Sekolah Tinggi Theologia Jaffray Makassar, 2016.

Wijaya, Hengki. "Pengenaan Manusia Baru Di Dalam Kristus: Natur, Proses, Dan Fakta Serta Implikasi Teologis Dan Praktisnya.” Jurnal Jaffray 14, no. 1 (March 22, 2016): 109-30. https://doi.org/10.25278/jj71.v14i1.194.

Wiseman, D. J. \& J.I Packer. Ensiklopedi Alkitab Masa Kini Jilid II. Jakarta: Yayasan Komunikasi Bina Kasih, 2013. 